ELŻBIETA HORSZCZARUK

West Pomeranian University of Technology Szczecin

e-mail: Elzbieta.Horszczaruk@zut.edu.pl
Manuscript submitted 2019.08.13 - revised 2019.09.20,

initially accepted for publication 2019.10.22, published in December 2019

\title{
PROPERTIES OF CEMENT MORTARS MODIFIED WITH COMMERCIAL NANOSILICA
}

\section{WŁAŚCIWOŚCI ZAPRAW CEMENTOWYCH MODYFIKOWANYCH NANOKRZEMIONKĄ KOMERCYJNĄ}

DOI: 10.30540/sae-2019-018

\begin{abstract}
Nanosilica as a commercial product dedicated to construction remains a relatively expensive chemical admixture for concrete and cement mortars. Economic considerations are a major barrier to the industrial use of nanosilica in the building materials industry. With respect to nanosilica, the following have been confirmed: accelerating the effect of $\mathrm{C}_{3} \mathrm{~S}$ hydration, accelerated $\mathrm{C}-\mathrm{S}$-H gel formation, modification of the mixture viscosity, improvement of cement matrix tightness, also at high temperature. The efficiency of nanosilica depends on its even distribution in the composite, therefore disagglomeration is necessary for the proper design of mortar or concrete. The article presents the results of tests on cement mortars modified with different amounts of colloidal nanosilica. It is an nano-SiO admixture in the form of an aqueous dispersion containing up to 50\% pure nanosilica, which is produced on an industrial scale as an admixture for concrete and cement mortars. Dispersions of nanosilica in composite using ultrasound were used. The possibilities of using nanosilica as an admixture improving the early strength of cement composites were pointed out.
\end{abstract}

Keywords: nanosilica, mechanical properties, cement mortars

\section{Streszczenie}

Nanokrzemionka jako produkt komercyjny dedykowany dla budownictwa pozostaje nadal stosunkowo droga domieszka chemiczna do betonów i zapraw cementowych. Względy ekonomiczne sa główna bariera w przemystowym zastosowaniu nanokrzemionki w przemyśle materiałów budowlanych. Wodniesieniu do nanokrzemionki potwierdzono: przyspieszające działanie na hydratację $C_{3} S$, przyspieszone tworzenia się żelu C-S-H, modyfikację lepkości mieszanki, poprawe szczelności matrycy cementowej, także w warunkach wysokiej temperatury. Wydajność nanokrzemionki zależy od jej równomiernego rozmieszczenia w kompozycie, dlatego dezaglomeracja jest niezbędna do prawidlowego zaprojektowania zaprawy lub betonu. W artykule przedstawiono wyniki badań zapraw cementowych modyfikowanych różna ilościa nanokrzemionki koloidalnej. Jest to domieszka nano-SiO ${ }_{2}$ w postaci wodnej dyspersji zawierającej do 50\% czystej nanokrzemionki, która produkowana jest na skale przemystowa jako domieszka do betonów i zapraw cementowych. W badaniach zastosowano dyspersję nanokrzemionki w kompozycie z wykorzystaniem ultradźwięków. Wskazano na możliwości zastosowania nanokrzemionki jako domieszki poprawiającej wczesna wytrzymałość kompozytów cementowych.

Słowa kluczowe: nanokrzemionka, właściwości mechaniczne, zaprawy cementowe

\section{INTRODUCTION}

Nano- $\mathrm{SiO}_{2}$, also known as silica nanoparticles or nanosilica, is silicon dioxide with the particles diameter less than $100 \mathrm{~nm}$. Nanosilica is one of the first nanomaterials, whose impact on the properties of the cement composites has been the most

\section{WPROWADZENIE}

Nano-SiO ${ }_{2}$, znany również jako nanocząstki krzemionki lub nanokrzemionka, jest ditlenkiem krzemu o średnicy mniejszej niż $100 \mathrm{~nm}$. Nanokrzemionka jest jednym z pierwszych nanomateriałów, którego wpływ na właściwości kompozytów cementowych 
widely studied, except to the carbon nanotubes. Application of nano- $\mathrm{SiO}_{2}$ did not lead yet to such spectacular achievements in the concrete technology as the use of silica fumes, usually called microsilica. However, nanosilica is considered the basic nanomaterial for creation the so-called nanoengineered concrete [1], i.e. concrete not only of very high strength, but also of special functional properties, which can be obtained by using nanomaterials. There are many different chemical methods of nanosilica production, eg. pyrolysis of tetraalkoxysilane or tetrachlorsilane (this method leads to the obtaining of the powdered nanosilica with irregular shape and size of particles), silica precipitation (from the solution of sodium silicate in the acid environment) or the sol-gel method [2]. These methods, due to the high costs of production, do not allow to industrially use the nanosilica for the production of cement and concrete. The cheapest method of the industrial production of nanosilica for the construction purposes is the grinding method, however, the nanostructures obtained with this method are heterogeneous and contaminated [3]. Most of the papers dealing with the modification of the cement composites with nanosilica presents the results of tests conducted with the use of chemically synthesized nano$\mathrm{SiO}_{2}$. The results of the researches have confirmed the acelerating effect of the nanosilica on the hydration of $\mathrm{C}_{3} \mathrm{~S}$ and production of C-S-H gel [4], modification of the viscisity [5] and improvement of the tightness of the cement matrix [6], also at the high temperature [7].

As the majority of the nanomaterials, nanosilica shows the tendency to agglomerate. The efficiency of nanosilica depends on its homogeneous distribution in the composite, therefore, its disagglomeration is necesary for the proper designing of the cement composite. The use of a superplasticizer is often not sufficient. The effective, but also expensive, method of application of nano- $\mathrm{SiO}_{2}$ is combination of sonication (ultrasounds) with the fast mechanical stirring [8].

Nanosilica as the commercial product, dedicated to the construction industry, is produced in the form of powder obtained by grinding of the waste cullet. The product contains the particles of nano$\mathrm{SiO}_{2}$ with diameters $60-300 \mathrm{~nm}$ and is dedicated as the admixture for the high-performance concretes, decorative concretes and shotcretes. The nano- $\mathrm{SiO}_{2}$ occurs also in the form of the water suspension, został najszerzej zbadany oprócz nanorurek węglowych. Zastosowanie nano- $\mathrm{SiO}_{2}$ nie doprowadziło jeszcze do tak spektakularnych osiągnięć w dziedzinie technologii betonu jak zastosowanie pyłów krzemionkowych, popularnie zwanych mikrokrzemionką. Nanokrzemionka jest jednak uważana za podstawowy nanomateriał do tworzenia tzw. nanoinżynierskiego betonu [1], tj. betonu nie tylko o bardzo wysokiej wytrzymałości, ale także specjalnych właściwościach użytkowych, których uzyskanie możliwe jest dzięki zastosowaniu nanomateriałów. Istnieje wiele różnych metod chemicznych wytwarzania nanokrzemionki np. piroliza tetraalkoksysilanu lub tertrachlorosilanu (metoda prowadząca do otrzymania sproszkowanej nanokrzemionki o nieregularnym kształcie i wielkości cząstek), strącanie krzemionki (w środowisku kwaśnym z roztworu krzemianu sodowego) czy metody zol-żel [2]. Metody te $\mathrm{z}$ uwagi na wysokie koszty produkcji nie pozwalają na przemysłowe wykorzystanie nanokrzemionki w przemyśle produkcji cementu i betonu. Najtańszą metodą przemysłowej produkcji nanokrzemionki na potrzeby budownictwa pozostaje metoda mielenia, jednak nanostruktury pozyskiwane tą metodą są niejednorodne i zanieczyszczone [3]. Większość publikacji dotyczących modyfikacji kompozytów cementowych nanokrzenionką prezentuje wyniki badań z zastosowaniem nano- $\mathrm{SiO}_{2}$ syntetyzowanej chemicznie. Badania kompozytów cementowych modyfikowanych nanokrzemionką potwierdziły jej przyspieszające działanie na hydratację $\mathrm{C}_{3} \mathrm{~S}$ i tworzenie się żelu C-S-H [4], modyfikację lepkości kompozytów [5] oraz poprawę szczelności matrycy cementowej [6], także w warunkach wysokiej temperatury [7].

Jak większość nanomateriałów nanokrzemionka ma skłonność do tworzenia skupisk zwanymi aglomeratami. Wydajność nanokrzemionki zależy od jej równomiernego rozmieszczenia w kompozycie, dlatego dezaglomeracja jest niezbędna do prawidłowego zaprojektowania kompozytu cementowego. Zastosowanie superplastyfikatora jest często niewystarczające. Skuteczną, jednak kosztowną metodą aplikacji nano- $\mathrm{SiO}_{2}$ jest połączenie sonikacji (ultradźwięki) z szybkim mieszaniem mechanicznym [8].

Nanokrzemionka jako produkt komercyjny dedykowany dla budownictwa produkowana jest $\mathrm{w}$ formie proszku powstałego ze zmielenia odpadowej stłuczki szklanej. Produkt ten zawiera cząsteczki nano- $\mathrm{SiO}_{2}$ o średnicy $60-300 \mathrm{~nm}$ i jest przeznaczony jako domieszka do betonów wysokowartościowych, betonów architektonicznych i torkretu. Jako produkt przemysłowy nano- $\mathrm{SiO}_{2}$ występuje również w posta- 
containing up to $50 \%$ of the pure silica and designed for the self-compacting and pre-cast concretes.

The results of the tests of the cement mortars modified with various amounts of colloidal nanosilica are presented in the paper. This is nano- $\mathrm{SiO}_{2}$ admixture in the form of the water suspension containing up to $50 \%$ of the pure nanosilica, produced in the industrial scale as the admixture for concretes and mortars. In order to evenly distribute the nano-admixture in water, sonication of the solution was used in addition to mechanical mixing.

\section{EXPERIMENTAL}

\subsection{Materials}

Portland cement CEM I 42.5R, conforming to the requirements of PN-EN 197-1, was used for preparation of the cement mortars. The chemical composition of the cement is presented in Table 1. The standard sand $0 \div 2 \mathrm{~mm}$ conforming to the PN-EN 196-1 was also used. The mortars were modified with the admixture of commercial nanosilica, in the form of the alkaline water dispersion containing about $50 \%$ (by mass) of the colloidal silica. The dispersion of silica is stabilized with sodium, and the particles of the amorphous silica have negative surface charge. The silica particles have smooth, spherical shape and are present in the wide distribution of the size. The dispersion is a white fluid, with the viscosity $(8 \mathrm{cP})$ and density $\left(1.4 \mathrm{~g} / \mathrm{cm}^{3}\right)$ slightly higher than that of water. The diameters of nanosilica measured using SEM were from 40 to $160 \mathrm{~nm}$. Four cement mortars were prepared with the content of nanosilica equal to $0 \%, 1 \%, 3 \%$ and $5 \%$ in relation to the cement mass. The samples of the mortars containing admixture of nano- $\mathrm{SiO}_{2}$ were marked, respectively, M0, M1, M3 and M5. The proportions of the components are presented in Table 2. For all mortars the amount of cement was constant and the w/c ratio was 0.5 . The water from the admixture was included into the composition of the mortars. ci zawiesiny wodnej zawierającej maksymalnie do $50 \%$ czystej krzemionki i jest przeznaczony do betonów samozagęszczalnych oraz betonów stosowanych w prefabrykacji.

W pracy przedstawiono wyniki badań zapraw cementowych modyfikowanych różną ilością nanokrzemionki koloidalnej. Jest to domieszka nano- $\mathrm{SiO}_{2}$ w postaci wodnej dyspersji zawierającej do $50 \%$ czystej nanokrzemionki, która produkowana jest na skalę przemysłową jako domieszka do betonów i zapraw cementowych. W celu równomiernego rozmieszczenia nanodomieszki w wodzie zastosowano oprócz mieszania mechanicznego sonikację roztworu.

\section{CZĘŚĆ DOŚWIADCZALNA}

\subsection{Materiały}

Do wykonania zapraw cementowych zastosowano cement portlandzki CEM I 42,5R spełniającym wymagania normy PN-EN 197-1, o składzie chemicznym podanym $\mathrm{w}$ tabeli 1 , oraz piasek normowy frakcji $0 \div 2$ mm zgodny z normą PN-EN 196-1. Zaprawy modyfikowano domieszką nanokrzemionki komercyjnej występującej w postaci alkalicznej wodnej dyspersji krzemionki koloidalnej, która stanowi około $50 \%$ wagowych części stałych. Dyspersja krzemionki jest stabilizowana sodem, a cząstki bezpostaciowej krzemionki mają ujemny ładunek powierzchniowy. Cząstki krzemionki, mają gładki, kulisty kształt i są obecne w szerokim rozkładzie wielkości cząstek. Fizyczny wygląd dyspersji to biały płyn o nieco wyższej lepkości niż woda $(8 \mathrm{cP})$ i gęstości $1,4 \mathrm{~g} / \mathrm{cm}^{3}$. Pomierzone średnice nanokrzemionki $\mathrm{z}$ wykorzystaniem analizy SEM wynosiły od $40 \mathrm{~nm}$ do $160 \mathrm{~nm}$. Wykonano cztery zaprawy cementowe o procentowej zawartości nanokrzemionki $\mathrm{w}$ stosunku do masy cementu wynoszącej odpowiednio: 0\%, 1\%, 3\% i 5\%. Próbki zapraw z domieszką nano- $\mathrm{SiO}_{2}$, w zależności od zawartości nanodomieszki, oznaczono symbolami M0, M1, M3 i M5. Proporcje składników zastosowanych do wykonania zapraw przedstawiono w tabeli 2. Dla wszystkich zapraw ilość cementu była stała, a wskaźnik w/c wynosił 0,5 . W składzie zapraw uwzględniono wodę występującą w domieszce.

Table 1. Chemical properties of cement used in cement mortars

Tabela 1. Skład chemiczny cementu do wykonania zapraw cementowych

\begin{tabular}{|c|c|c|c|c|c|c|c|c|c|c|c|}
\hline Material & $\mathrm{CaO}$ & $\mathrm{SiO}_{2}$ & $\mathrm{Al}_{2} \mathrm{O}_{3}$ & $\mathrm{Fe}_{2} \mathrm{O}_{3}$ & $\mathrm{FeO}$ & $\mathrm{MgO}$ & $\mathrm{Na}_{2} \mathrm{O}$ & $\mathrm{K}_{2} \mathrm{O}$ & $\mathrm{SO}_{3}$ & $\mathrm{BaSO}_{4}$ & $\mathrm{TiO}_{2}$ \\
\hline $\begin{array}{c}\text { CEM I } \\
42.5 \mathrm{R}\end{array}$ & 63.3 & 19.5 & 4.9 & 2.9 & 0.01 & 1.3 & 0.1 & 0.9 & 2.8 & 0.1 & 0.01 \\
\hline
\end{tabular}


Table 2. Mix proportions of cement mortars

Tabela 2. Proporcje składników zapraw cementowych

\begin{tabular}{|c|c|c|}
\hline Cement type & Nano-SiO ${ }_{2}$ content & Sand type \\
\hline CEM I 42.5 R & $\begin{array}{c}0,1,3,5 \\
\text { (mass \% of C) }\end{array}$ & Standard sand \\
\hline
\end{tabular}

Before introducing into the cement, the nano- $\mathrm{SiO}_{2}$ admixture was mixed with the mixing water, using the mechanical stirrer. Simultaneously, the mixture of the mixing water and admixture was dispersed by sonication, in order to obtain the homogeneous suspension of $\mathrm{SiO}_{2}$ in water. This mixture was added to the cement, using the standard mortar mixer. Times of mixing of the particular components of the mortars are presented in Table 3. The mortar without nano$\mathrm{SiO}_{2}$ was prepared according to PN-EN 196-1.
Przed wprowadzeniem nano-SiO $\mathrm{Si}_{2}$ do cementu, domieszkę wymieszano z wodą zarobową z zastosowaniem mieszadła mechanicznego. Jednocześnie mieszaninę wody zarobowej i domieszki poddano dyspersji przez sonikację w celu uzyskania jednorodnej zawiesiny $\mathrm{SiO}_{2}$ w wodzie. Tak powstałą mieszaninę dozowano do cementu, stosując normową mieszarkę do zapraw. Czasy mieszania poszczególnych składników zapraw przedstawiono w tabeli 3. Zaprawę bez domieszki nano-SiO 2 wykonano zgodnie z normą PN-EN 196-1.

Table 3. Main fabrication process of cement mortars with nano-SiO

Tabela 3. Sposób wykonania zapraw cementowych z nano-SiO

\begin{tabular}{|c|c|c|c|c|c|c|}
\hline \multirow{2}{*}{ Feeding order } & \multicolumn{2}{|c|}{ Technology } & \multicolumn{2}{|c|}{ Moulding } & \multicolumn{2}{|c|}{ Curing } \\
\hline & Method & Time & Method & Size/mm & Conditions & Time \\
\hline Water+nano-SiO & $\begin{array}{l}\text { Shear mixing (300 rot/min) } \\
\text { and ultrasonication }\end{array}$ & $10 \mathrm{~min}$ & \multirow{5}{*}{ Vibration } & \multirow{5}{*}{$\begin{array}{l}40 \times 40 \times 160 \mathrm{~mm} \\
\text { (mechanical test) }\end{array}$} & \multirow{5}{*}{$\begin{array}{l}\text { Air }\left(20 \pm 2^{\circ} \mathrm{C} \text {, }\right. \\
\text { at RH } 95 \%)\end{array}$} & \multirow{5}{*}{$\begin{array}{l}2 \text { days } \\
28 \text { days }\end{array}$} \\
\hline Cement & Shear mixing (at low speed) & $60 \mathrm{~s}$ & & & & \\
\hline- & Shear mixing (at fast speed) & $30 \mathrm{~s}$ & & & & \\
\hline Sand & Shear mixing (at low speed) & $30 \mathrm{~s}$ & & & & \\
\hline- & Shear mixing (at high speed) & $60 \mathrm{~s}$ & & & & \\
\hline
\end{tabular}

\subsection{Methods of testing}

The consistence of the mortars was determined using the flow table, according to PN-EN 1015-3. The consistence tests were carried out every 15 minutes within the period of 60 minutes from the finish of mixing the components. Before starting the next measurement, every mortar was mixed for 30 seconds in the mortar mixer at the low speed (140 rt/min).

The specimens for the mechanical tests were prepared in the form of the standard beams $4 \times 4 \times 16 \mathrm{~cm}$. The specimens were demoulded after 24 hours of storing in the climate chamber at the temperature $20 \pm 2^{\circ} \mathrm{C}$ and relative humidity $95 \%$.

\subsection{Metody badań}

Konsystencję zapraw oznaczono za pomocą stolika rozpływu zgodnie z normą PN-EN 1015-3. Badania konsystencji zapraw prowadzono co 15 minut przez okres 60 minut od momentu zakończenia mieszania składników. Przed rozpoczęciem kolejnego badania każdą zaprawę mieszano przez 30 sekund w mieszarce do zapraw z niską prędkością (140 obr/min.).

Próbki do badań właściwości mechanicznych zapraw uformowano $\mathrm{w}$ postaci standardowych belek prostopadłościennych o wymiarach $4 \times 4 \times 16 \mathrm{~cm}$. Próbki rozformowano po 24 godzinach przechowywania w komorze klimatycznej w temperaturze 
The way of preparing and curing of the specimens until testing is presented in the Table 3 . The tests of the mechanical properties of the mortars were conducted after 2 and 28 days of curing. Six specimens were prepared for every mortar. Flexural and compressive strength was stermind according to PN-EN 196-1.

\section{RESULTS AND DISCUSSION}

\subsection{Consistence of the mortars}

The results of tests of the influence of nano- $\mathrm{SiO}_{2}$ on the consistence of fresh mortars as a function of time are presented in Figure 1. A clear effect of the content of nano- $\mathrm{SiO}_{2}$ admixture on the change of consistence of the mortars can be observed, both immediately after mixing of the components and within the next 60 minutes.

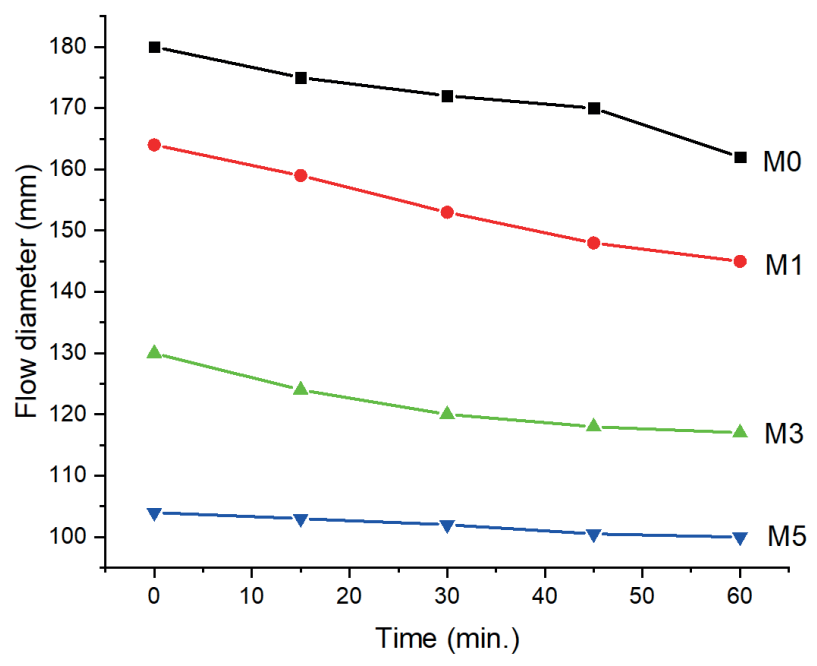

Introduction of nano- $\mathrm{SiO}_{2}$ into the cement mortars have caused decreasing of the flow with growing admixture content. Nanosilica, like other nanomaterials, due to the high ratio of the specific area to the volume shows high water demand, and thus the content of the free water in the cement composite is decreasing with growing amount of nanosilica $[9,10]$.

The mortar with low content of nano-SiO 2 (M1) has demonstrated relatively good workability and stability of consistence within 60 minutes from mixing of the components. The mortars with high content of nano- $\mathrm{SiO}_{2}$ (M3 and M5), however, have demonstrated significant fall of the consistence and, as a consequence, have poor workability. In the case of the mortar M5, the poor workability
$20 \pm 2^{\circ} \mathrm{C}$ i wilgotności względnej 95\% Sposób formowania i przechowywania próbek zapraw do czasu badania właściwości mechanicznych przedstawiono w tabeli 3. Badania właściwości mechanicznych zapraw przeprowadzono po 2 i 28 dniach dojrzewania. Dla każdej z zapraw wykonano po 6 próbek i oznaczono wytrzymałość na zginanie i ściskanie zgodnie z normą PN-EN 196-1.

\section{WYNIKI I DYSKUSJA}

\subsection{Konsystencja zapraw}

Wyniki badań wpływu nano- $\mathrm{SiO}_{2}$ na konsystencję świeżych zapraw w funkcji czasu przedstawiono na rysunku 1 . Widoczny jest wyraźny wpływ ilości domieszki nano- $\mathrm{SiO}_{2}$ na zmianę konsystencji badanych zapraw, zarówno bezpośrednio po wymieszaniu składników, jak i w badanym przedziale czasowym 60 minut.

Fig. 1. Flow diameter of the tested mortars as a function of time Rys. 1. Średnica rozplywu badanych zapraw w funkcji czasu

Wprowadzenie nano-SiO 2 do zapraw cementowych spowodowało zmniejszanie rozpływu wraz ze wzrostem zawartości domieszki. Nanokrzemionka, podobnie jak i inne nanomateriały, z uwagi na duży stosunek powierzchni właściwej do objętości, cechuje się dużą wodożądnością, przez co ilość wolnej wody w kompozycie cementowym zmniejsza się wraz ze wzrostem jej zawartości w kompozycie $[9,10]$.

Zaprawa z niską zawartością nano-SiO $\mathrm{S}_{2}$ (M1) wykazuje stosunkowo dobrą urabialność i dobrą stabilność konsystencji w przeciągu 60 minut od wymieszania składników. Domieszka 1\% nanokrzemionki nie spowodowała spadku urabialności zaprawy w badanym czasie. Jednak zaprawy o dużej zawartości nano-SiO ${ }_{2}$ (M3 i M5) wykazują znaczny spadek konsystencji, a co za tym idzie, wykazują słabą urabialno- 
was observed immediately after mixing of the components. This leads to the extended time of compaction during preparation of the specimens. The testing of consistence reveals the necessity of the use of superplasticizers when higher amount of nano- $\mathrm{SiO}_{2}$ (above $1 \%$ of the cement mass) is used, for obtaining the required workability of the mortars and limiting the excess of pores.

\subsection{Flexural and compressive strength}

The relation between the content of nano- $\mathrm{SiO}_{2}$ and the flexural strength of the tested mortars are presented in Figure 2. The Table 4 presents the growth of the rate of flexural strength development after 2 and 28 days of curing. Analysis of the Figure 2 shows that the admixture of nano- $\mathrm{SiO}_{2}$ caused an increase of the flexural strength. The maximum growths of strength were observed at 3\% of nano$\mathrm{SiO}_{2}$ content in the mortar (M3). The higher increases of flexural strength were observed for the mortars after 2 days of curing (up to $24.5 \%$ for the mortar M3). The growth of 28-day flexural strength was lower and did not exceed $20 \%$ in relation to the standard mortar.

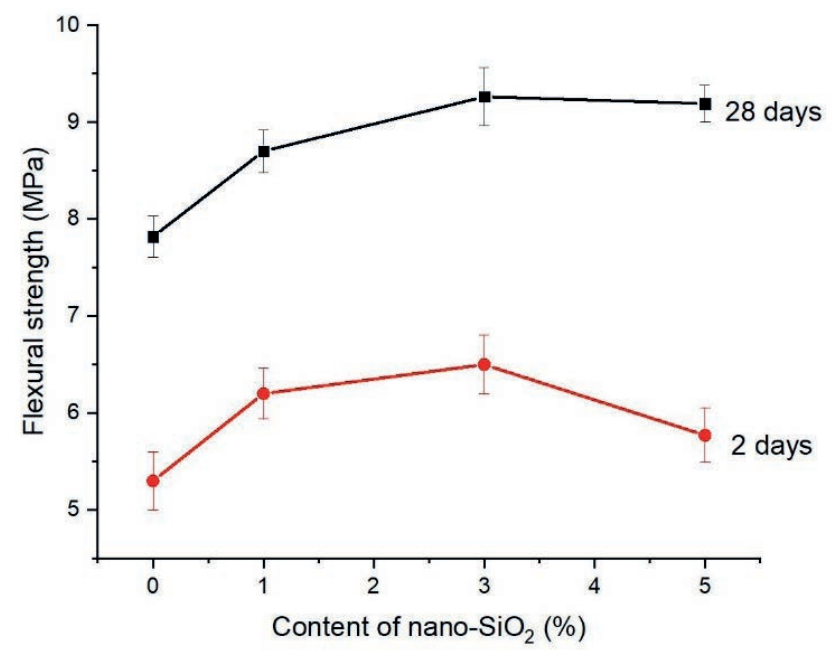

ścią. W przypadku zaprawy M5 już po wymieszaniu składników obserwowano bardzo niską urabialność, co skutkowało koniecznością zastosowania wydłużonego czasu zagęszczania zapraw przy formowaniu próbek do badań mechanicznych. Badania konsystencji pokazują bezwzględną konieczność stosowania superplastyfikatorów przy zastosowaniu większych ilości nano- $\mathrm{SiO}_{2}$ (powyżej 1\% m.c) w celu uzyskania wymaganej urabialności zapraw i ograniczenia nadmiernej ilości porów.

\subsection{Wytrzymałość na zginanie i na ściskanie}

Zależność pomiędzy zawartością nano- $\mathrm{SiO}_{2}$ a wytrzymałością na zginanie badanych zapraw przedstawiono na rysunku 2. Tabela 4 przedstawia wzrost szybkości wytrzymałości na zginanie zapraw cementowych po 2 i 28 dniach dojrzewania. $Z$ analizy rysunku 2 wynika, że domieszka nano- $\mathrm{SiO}_{2}$ powoduje przyrost wytrzymałości zapraw na zginanie. Maksymalne przyrosty wytrzymałości obserwowano przy $3 \%$ zawartości nano- $\mathrm{SiO}_{2}$ w zaprawie (M3). Większe przyrosty wytrzymałości na zginanie obserwowano dla zapraw po 2 dniach twardnienia (do $24,5 \%$ dla zaprawy M3). Przyrost 28-dniowej wytrzymałości na zginanie był niższy i nie przekroczył $20 \% \mathrm{w}$ stosunku do zaprawy normowej.

Fig. 2. Flexural strength of cement mortar with nano-SiO at curing ages of 2 and 28 days

Rys. 2. Wytrzymałość na zginanie zapraw cementowych z nano-SiO ${ }_{2}$ po 2 i 28 dniach dojrzewania

Table 4. Increase of flexural and compressive strength of cement mortars with different content of nano-SiO Tabela 4. Przyrost wytrzymałości na zginanie i ściskanie zapraw cementowych z różna zawartościa nano-SiO ${ }_{2}$

\begin{tabular}{|l|c|c|c|c|c|c|}
\hline \multirow{2}{*}{ Curing age } & \multicolumn{3}{|c|}{ Flexural strength (\%) } & \multicolumn{3}{c|}{ Compressive strength (\%) } \\
\cline { 2 - 7 } & With 1\% of nano-SiO & With 3\% of nano-SiO & With 5\% of nano-SiO & With 1\% of nano-SiO ${ }_{2}$ & With 3\% of nano-SiO & With $\mathbf{5} \%$ of nano-SiO $_{2}$ \\
\hline 2 days & 17.0 & 24.5 & 8.9 & 11.6 & 30.1 & 21.2 \\
\hline 28 days & 11.3 & 18.4 & 17.5 & 11.0 & 32.5 & 25.2 \\
\hline
\end{tabular}


The Figure 3 presents the relation between the compressive strength of the tested mortars and the content of nano- $\mathrm{SiO}_{2}$.

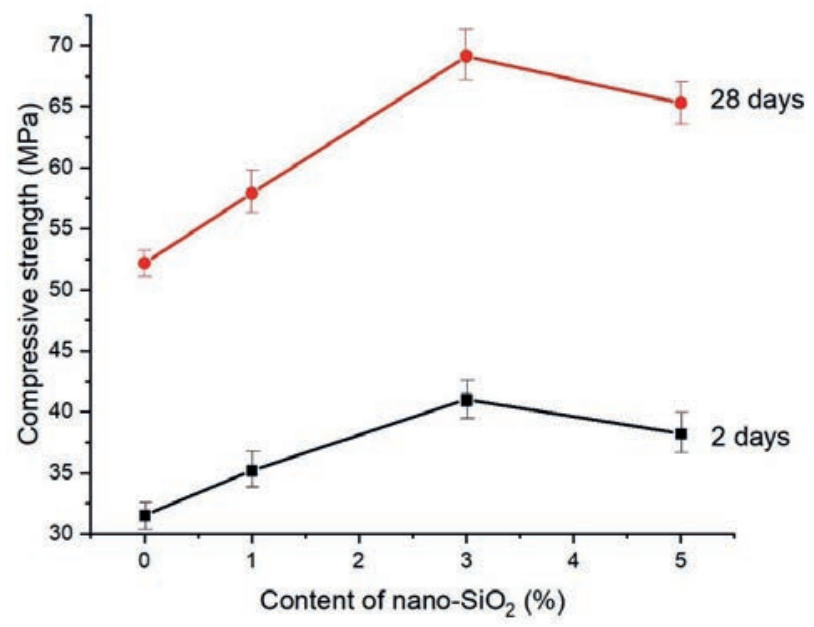

The analysis of the Figure 3 and the data from the Table 4 shows that the growths of the strength after both 2 and 28 days were similar for the mortars with the same content of nano- $\mathrm{SiO}_{2}$. The maximum compressive strength was noted for the mortar with $3 \%$ of nano- $\mathrm{SiO}_{2}$ (the mortar $\mathrm{M} 3$ ). At $3 \%$ content of nano- $\mathrm{SiO}_{2}$, the more than $30 \%$ increase of the compressive strength after 2 and 28 days of curing was observed. The $3 \%$ content of the admixture of nanosilica seems to be an optimum, considering the improvement of the mechanical properties of the tested mortars. Due to the downfall of the workability of the mortar M3, however, the use of a superplasticizer is necessary. According to the number of the researches reported in the literature, the significant worsening of the physico-mechanical properties of the cement composites modified with nano- $\mathrm{SiO}_{2}$ was observed most often at $5 \%$ content of nano- $\mathrm{SiO}_{2}$ [11-14]. The large amount of nano- $\mathrm{SiO}_{2}$ in cement composites creates significant problems in the even distribution of nanomaterial in the matrix, which results in the formation of agglomerates (Fig. 4). Nanoparticle agglomerates are the cause of local matrix weakening. This is the result of a greater demand for water for nanoparticles, which causes a local increase in the porosity of the capillary matrix in the vicinity of agglomerates $[8,15]$.
Na rysunku 3 przedstawiono zależność pomiędzy zawartością nano- $\mathrm{SiO}_{2}$ a wytrzymałością na ściskanie badanych zapraw.

Fig. 3. Compressive strength of cement mortar with nano-SiO ${ }_{2}$ at curing ages of 2 and 28 days

Rys. 3. Wytrzymałość na ściskanie zapraw cementowych $z$ nano-SiO ${ }_{2}$ po 2 i 28 dniach dojrzewania

$\mathrm{Z}$ analizy rysunku 3 i danych z tabeli 4 wynika, że zarówno dla wczesnej wytrzymałości na ściskanie, jak i wytrzymałości 28-dniowej przyrosty wytrzymałości były zbliżone dla zapraw o tej samej zawartości nano- $\mathrm{SiO}_{2}$. Maksymalną wytrzymałość na ściskanie zanotowano dla zapraw o zawartości $3 \%$ nano- $\mathrm{SiO}_{2}$ (zaprawa M3). Przy zawartości 3\% nano-SiO 2 obserwowano ponad $30 \%$ wzrost wytrzymałości na ściskanie po 2 i 28 dniach dojrzewania. Ilość 3\% domieszki nanokrzemionki w zaprawie wydaje się wartością optymalną, biorąc pod uwagę poprawę właściwości mechanicznych badanych zapraw, jednak z uwagi na spadek urabialności zapraw M3 konieczne jest zastosowanie superplastyfikatora. Jak wykazują stosunkowo liczne badania publikowane w literaturze, wyraźne pogorszenie cech fizykomechanicznych kompozytów cementowych modyfikowanych nano- $\mathrm{SiO}_{2}$ obserwowano najczęściej już przy $5 \%$ zawartości nano- $\mathrm{SiO}_{2}$ w kompozycie [11-14]. Duża ilości nano-SiO $\mathrm{S}_{2}$ w kompozytach cementowych stwarza znaczące problemy $\mathrm{w}$ równomiernym rozmieszczeniu nanomateriału w matrycy, co skutkuje tworzeniem się aglomeratów (rys. 4). Aglomeraty nanoczastek są przyczyną lokalnego osłabienia matrycy. Jest to wynikiem większego zapotrzebowania na wodę nanocząstek, co powoduje lokalne zwiększenie porowatości kapilarnej matrycy w sąsiedztwie aglomeratów $[8,15]$. 


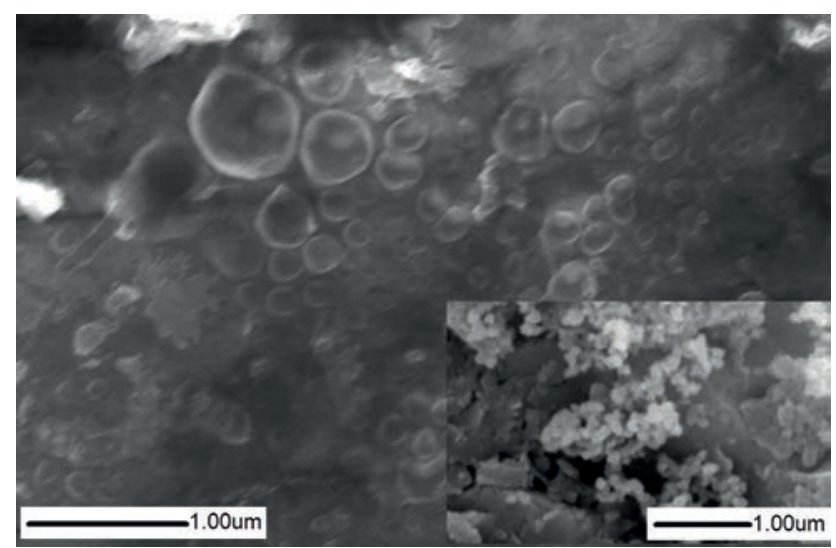

\section{CONCLUSIONS}

On the basis of the performed tests and analyses, the following conclusions can be formulated:

- admixture of nanosilica improves the mechanical properties of the cement mortars. However, at the higher contents of the admixture in the composite, this effect can be diminished;

- nano- $\mathrm{SiO}_{2}$ shows a practical potential as the admixture for the concrete pre-cast elements, because its use in the cement composites improves the early-age compressive and flexural strength;

- increasing content of nanosilica worsens the mortars workability, therefore at the higher contents of nano- $\mathrm{SiO}_{2}$ a superplasticizer should be included into the composition of mortars and concretes;

- on the basis of the performed tests and the review of the literature, it can be accepted that the content of nano- $\mathrm{SiO}_{2}$ in relation to the cement mass, in order to achievement of the desired properties of the composite, should not exceed 5\%.
Fig. 4. SEM micrograph of the agglomeration of silica nanospheres [15]

Rys. 4. Mikrografia SEM aglomeratów nanosfer krzemionkowych [15]

\section{WNIOSKI}

Na podstawie wykonanych badań i analiz można sformułować następujące wnioski:

- domieszka nanokrzemionki poprawia właściwości mechaniczne zapraw cementowych, jednak przy większych ilościach domieszki w kompozycie efekt poprawy wytrzymałości mechanicznej może ulec zmniejszeniu;

- nano-SiO ${ }_{2}$ wykazuje potencjał praktyczny jako domieszka stosowana przy produkcji prefabrykatów betonowych, gdyż jej zastosowanie w kompozytach cementowych poprawia wczesną wytrzymałość na ściskanie i rozciąganie;

- zwiększenie dodatku nanokrzemionki pogarsza urabialność zapraw, dlatego przy zastosowaniu większych ilości domieszki nano- $\mathrm{SiO}_{2}$ należy w składzie zapraw i betonów uwzględnić zastosowanie superplastyfikatora;

- na podstawie wyników badań oraz przeglądu literatury można przyjąć, że zawartość nano- $\mathrm{SiO}_{2}$ $\mathrm{w}$ stosunku do masy cementu w celu uzyskania pożądanych właściwości kompozytu nie powinna przekraczać 5\% masy spoiwa.

\section{REFERENCES}

[1] Sobolev K.: Modern developments related to nanotechnology and nanoengineering of concrete. Frontiers of Structural and Civil Engineering.10(2): 2016, 131-141, ISSN: 2095-2449.

[2] Cendrowski K., Sikora P., Horszczaruk E., Mijowska E.: Waste-free synthesis of silica nanospheres and silica nanocoatings from recycled ethanol-ammonium solution, Chemical Papers, 71(4), 2017, 841-848, ISSN: 2585-7290.

[3] Lim H.M. et all.: Comparative Study of Various Preparation Methods of Colloidal Silica. Engineering, 2, 2010, 998 1005. ISSN:1947-3931.

[4] Ye Q., Zhang Z., Kong D., Chen R.: Influence of nano-SiO ${ }_{2}$ addition on properties of hardened cement paste as compared with silica fume. Construction and Building Materials, 21(3), 2007, 539-45, ISSN: 0950-0618.

[5] Quercia G., Spiesz P., Hüsken G., Brouwers H.J.H.: SCC modification by use of amorphous nano-silica. Composites Part B, 81, 2015, 120-129, ISSN: 1359-8368.

[6] Singh L.P., Karade S.R., Bhattacharyya S.K., Yousuf M.M., Ahalawat S.: Beneficial role of nanosilica in cement based materials - A review. Construction and Building Materials, 47, 2013, 1069-1077, ISSN: 0950-0618.

[7] Horszczaruk E., Sikora P., Cendrowski K., Mijowska E.: The effect of elevated temperature on the properties of cement mortars containing nanosilica and heavyweight aggregates. Construction and Building Materials, 137, 2017, 420-431, ISSN: 0950-0618. 
[8] Johna E., Matscheib T., Stephan D.: Nucleation seeding with calcium silicate hydrate - A review. Cement and Concrete Research. 113, 2018, 74-85, ISSN: 0008-8846.

[9] Sikora P. Łukowski P., Cendrowski K., Horszczaruk E., Mijowska E.: The Effect of Nanosilica on the Mechanical Properties of polymer-Cement Composites (PCC), Procedia Engineering, 108, 2015, 139-145, ISSN: 1877-7058.

[10] Flores I., Pradoto R. G.K., Moini M., Kozhukhova M., Potapov V., Sobolev: The effect of $\mathrm{SiO}_{2}$ nanoparticles derived from hydrothermal solutions on the performance of Portland cement based materials. Frontiers of Structural and Civil Engineering, 11,4, 2017, 436-445, ISSN: 2095-2430.

[11] Zhang P., Zhao Y-N., Li Q-F., Zhang T-H., Wang P., Mechanical properties of fly ash concrete composite reinforced with nano-SiO and steel fiber, Current Science, 106, 11, 1529-1537 (2014).

[12] Wang B.: Inft uence of nano-SiO ${ }_{2}$ on the strength of high performance concrete, Materials Science Forum, 686, 2011, 432-437, ISSN: 1662-9752.

[13] Li G.: Properties of high-volume fly ash concrete incorporating nano-SiO ${ }_{2}$. Cement and Concrete Research. 34,2004, 1043-1049, ISSN: 0008-8846.

[14] Horszczaruk E.: Role of nanosilica in the formation of the properties of cement composites, state of the art. Cement Wapno Beton, 6, 2018, 487-495, ISSN 1425-8129.

[15] Horszczaruk E., Mijowska E., Cendrowski K., Mijowska S., Sikora P.: Effect of incorporation route on dispersion of mesoporous silica nanospheres in cement mortar. Construction and Building Materials 66, 2014, 418-421, ISSN: 0950-0618.

\section{Acknowledgments:}

The work was financed by the West Pomeranian University of Technology in Szczecin, Faculty of Civil Engineering and Architecture

\section{Podziękowania:}

Praca była finansowana przez Zachodniopomorski Uniwersytet Technologiczny w Szczecinie, Wydziat Budownictwa i Architektury 